\title{
PATHOLOGICAL STUDIES BY MEANS OF BIOPSY ON THE CHANGES IN THE LIVERS OF LEPROSY PATIENTS AND MURINE LEPROSY RATS
}

(I. Report) Tuberculoid Granuloma found in the Livers of Macular Cases by Puncture Biopsy

\author{
Seitarô Okada \\ National Leprosarium Tama Zenshôen
}

By means of puncture biopsy of the liver's of 5 macular cases complicated with no tuberculosis and syphilis I found a typical tuberculoid lesion in the liver of one case and atypical tuberculoid lesions in 4 cases. Through experimental evidences and considerations I have come to the conclusion that these lesions were leprous. In addition to these lesions I found the lesions which were regarded as various stages of formation of granuloma from initial lesion to such typical tuberculoid lesion, and followed the course of formation of tuberculoid granuloma in the liver lobule.

\section{ビオプシーによろ人瀨及鼠獺の肝臓病変の 病理組織学的研究}

\section{（第 1 報） 斑紋癩患者に於忷る肝藏の癩性病変; 類結 核性內臟癩に就て}

多既全生䝰（園長 林 芳信）

\author{
周罒誠太郎 \\ (昭和28年 8 月 5 日受稿)
}

\begin{abstract}
緒言
內藏衤の病理組織学的研究は之沦多数の論文が発表さ

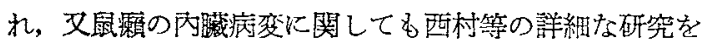
坮めとして內外亘り多数の研究が岕る。しかし Bio-

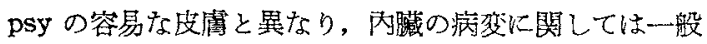
に Biopsy が困難ですった為に従来の研究は特殊な場合 を除いて殆どが Autopsy によってなされてきた。その 為に內臟病変の病理に関しては多くの直点が未開拓のま まに残されて今日に洷った。例へば內臟の瀨性病变の進
\end{abstract}

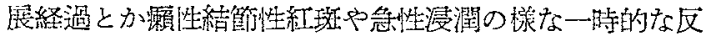
応の出現時に內臟に如何なる一邀性の变化が起るか，或

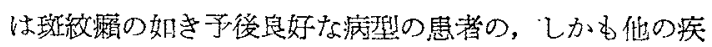

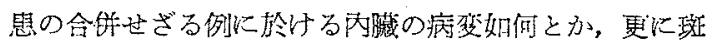

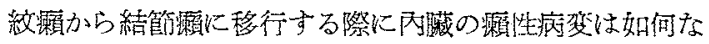
る推移を示すか，文各種治療剂によって队藏の病变が近

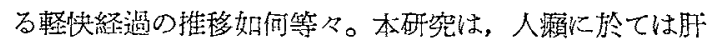

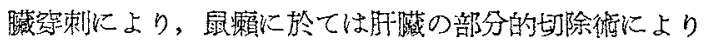
Biopsy を行い，それにより之等の領域の一端を硯こ5 としたものである。 


\section{訨臟穿刺に就て}

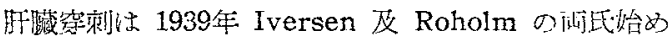

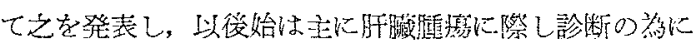
行われ，組織片を吸引してての組織片を調べる目的の下 に行わ礼, Bingle Olivet(1), Müller, Baron, Birk-

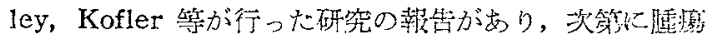
のみならず㮔々の肺疾貟の診断の虑に月いいられ，Difle， Mc. Michael(2)及 Sherlock 等を始め特沈英国及久y ンデナビアの学者により広沉な研究が行かれた。我国に

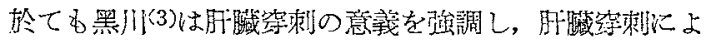
って始めて診断のできた例を紹介乙，更に参木(4)(5)(6)，

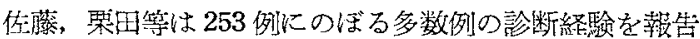
している。文鶴丸(7) は独査の窥测器を考案した。この 問，空刺の部位，方法等炕関し種及の方式が試みられて きた。本研究火際して怯之等墸家の報告及 Napier,

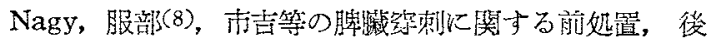
㚭置等を参考として，次の如さ方法で行った。

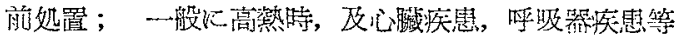
を始め循環障的及呵吸障待のあるるのは澼けることは勿 諭である。著明な化膿巢のるるるのも避ける。出血時間 血液凝固時間を調べる。服部，南吉は经血時間10分以下

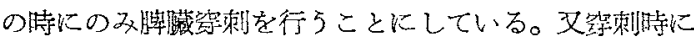
呼吸を行う之肝に裂創を生ぜしめ，出舟死の恐れがある

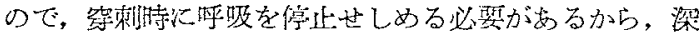

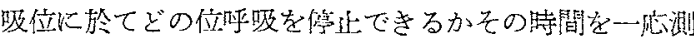
っておくことは，沵刺時の㭙間的な余裕の見当をつけう

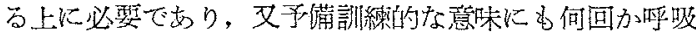
停止をさせてみること梳必要である。咳濑のあるちのは 避けた方がよい。肺の大さ，呼吸化体移動の程度，樑

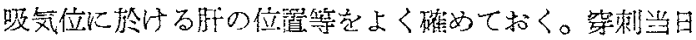
は朝食をとらせず，朝窥刺を行う。架刺前炕必ず排尿， 排便をさせる。要すれば浣腸をる行った。術前約30分比 ナルコポンを注射しておく。

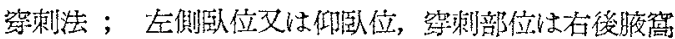
線第9 11肋間，ノボカインで究剌部位に浸潤踦醉を行 弓。综刺器としては始は內湰 $1.5 \mathrm{~mm}$ 長さ $10 \mathrm{~cm}$ の伏端 銃利な套管針を肞い，腹壁貫通後內針を奴き注射筒を接 続して肝に刺入し何回か針を备䡛させながら少し戻して は攵制入することを繰返し，肝組織を細挫してから吸引

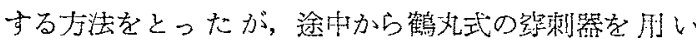

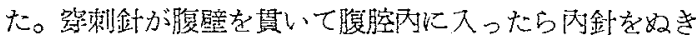

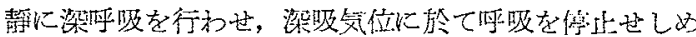

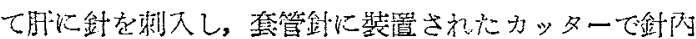

に入った円简状の肝組織の基部を切断して針をぬるくこ

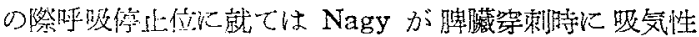
腹膜安射が起ることに注澺し，深吸気位に於て愺朦究刺 学行らことを提晿している。

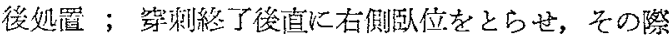

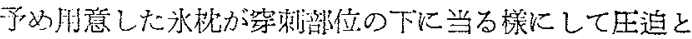

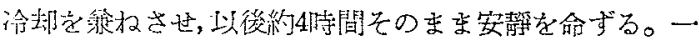
方体位轉換後顽化引゙ラチン液，ビタミン K，トロンボ 一グン，カルシウム等各種の止血威を注射する。量食は

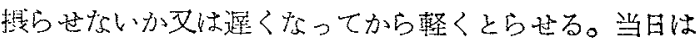

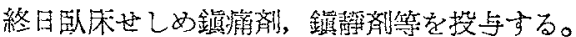

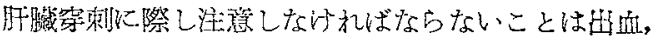
細藏感染, 路接器官殊に胆虽の損楊等であり, 殊火出血

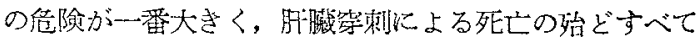

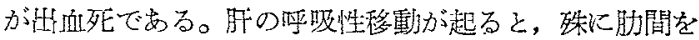

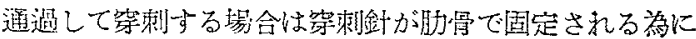
十分動かず䀒洷創を生じ大出血を起す。Olivet(1) 胁骨弓值下，胆要の右成は在に於て水本面に対し 30 ～

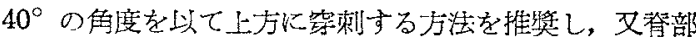
右肺の下界から 2 櫝指下の所で上外方に穿刺する方法る 上いと云っている。文組織片吸引後注射器を針から離し 針はそのままとして 3 c.c. の Clauden を入れた別の注 射器を接続し稌々に引きながら Clauden を実質中に注 人することを行っている。Mc Michael (2) 怯管針の

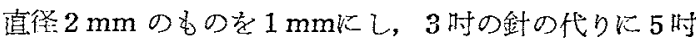
のものを用いて表面近い組織でなく比較的深部の組織を

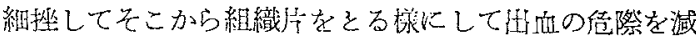
少さしめ得大と云う。一方かかる驾剩法自体织関する考

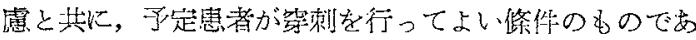
るか否かの診定と前处置，後処置飞刘与る十分なる考慮 が必裂で必る。

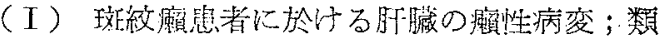
結核胜内薜瀨に就て

（本猃文の要昌は1951年秋の第 1 回東部地方会及1952年 4 月の第 25 回日本䧸学会化発表した〉

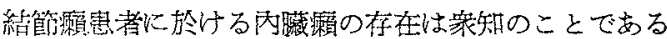

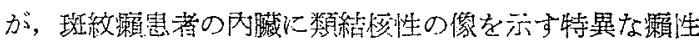
病资が存在することが交るか否かという問题に就ては， 今日飞王るも圭だ確たる解決を見ていない。これは主

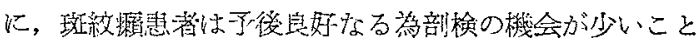
更びも乙機会があったとしても，そしてもしその內瀻に

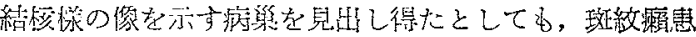

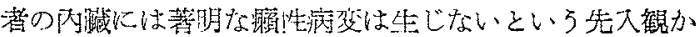


ら結核性の病樂として見過してしまうか，又湘生のむの

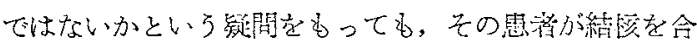

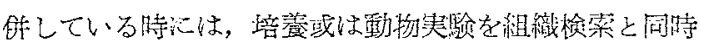

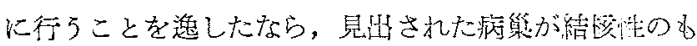
のでなく洒泩の病巢であると断定することは困婔でする という理由によるものである。その批梅毒，頪闪霆そ

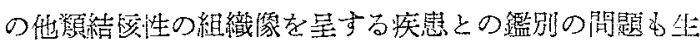
じてくる。

古< Danielsen and Boeck (1847) が, 稍後保 Arning(1894)(9)が瀬患者の內臟に見出した類結四性 病䒩を報告し, Arning の例飞就ては後に Schäffer(19 00)(10)が更にその詳細な所見を記述している。しかし

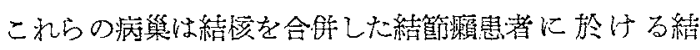
核性苪巢を誤諮したものではないかと教へられている。 また Rikli(1892)(11)はその福の病理解剖関する報告 の中に，Nägeliより䢪られた材料である肝臟の小装队

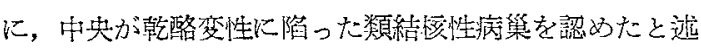

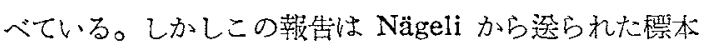
である肝と腪に就てしか記进してなく，他の器官の所見 には触れて居らずしか子肝と蛽の所罢の記述にも多くの

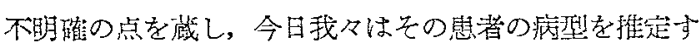

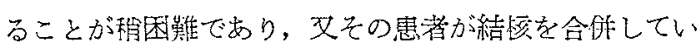
たか否かということが眀でない。そしてその病壆が結楆 性のものではないといら彼の断定の根挺は非常に薄弱で

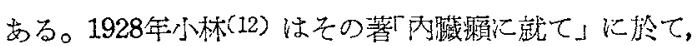

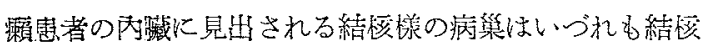

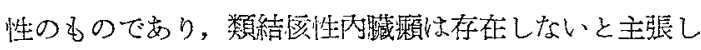
ている。Klingmüller(13) 你彼の著「Die Lepra」に次 の胡く記載している。即 Wade と Pineda (1929)は

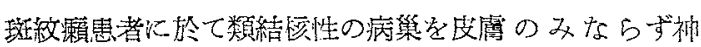

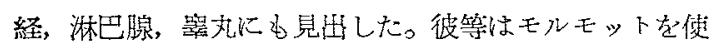

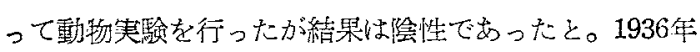

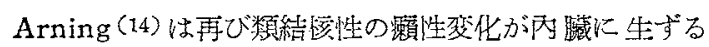
か唇かといら開题を提起し，この問题に関して研究すべ きことを主張し，之に閣して多数の賴学者による Symposium が行はれたが，一般に検案の機会のないことが 指摘され，その将来代於ける何らかの新しい方法による 解決が期待点れるに止まった。この際 Müller 等は類結

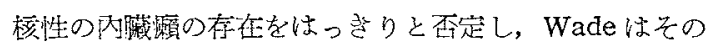

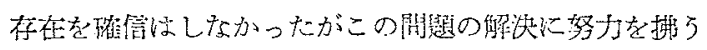

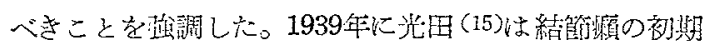

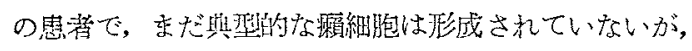

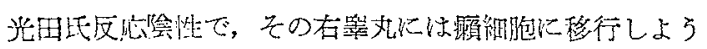
としている細胞の浸澖か思られる例の部湌に於て，その

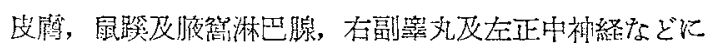

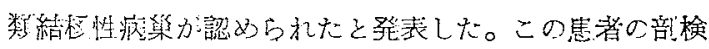

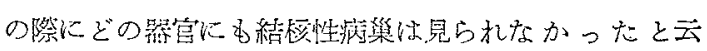

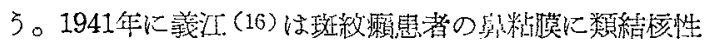

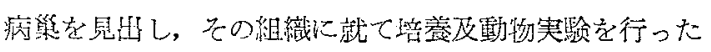

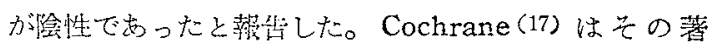
「A practical Textbook of Leprosy (1947) K坽て

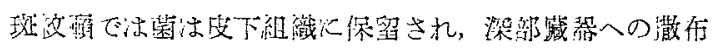
が起らないとしている。1950年に Campos と Molina (18) 注開腹衡行ってから朋の一部を切除し，その切

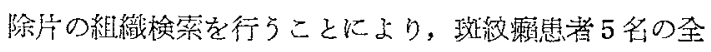

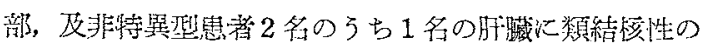

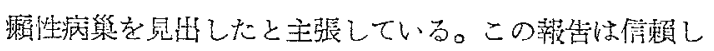
得るものであるが，大火結核の除外が監和的な観繁のみ

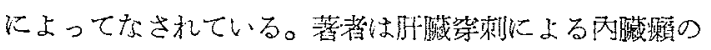

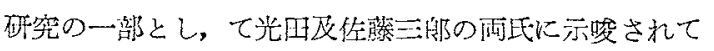
本研究に洋手した。

\section{実 験 方 法}

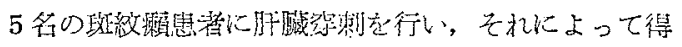

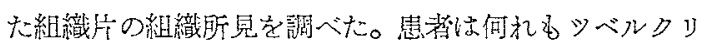

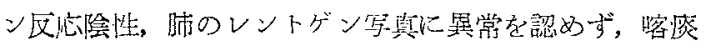

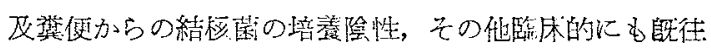

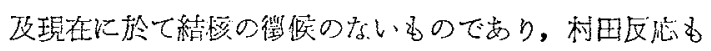

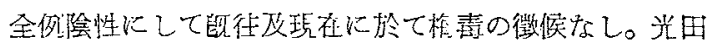

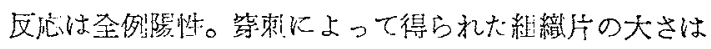
直径約 $2.0 \mathrm{~mm}$ 镸さ約 $1 \mathrm{C} \sim 2 \mathrm{Crm}$ 。 パシフイン包埧を行 い遭統切片をつくり，4炇置き飞 2 枚宛の切片をとり， らち1枚をい、トキシリン・エオジンで，他の1枚をチ ール・、マキシリンで梁め鋀梌した。1例につき入十 乃至百数十枚の那片を調べた。

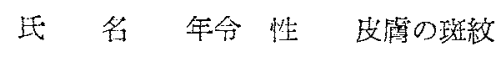

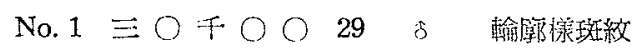

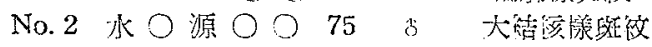

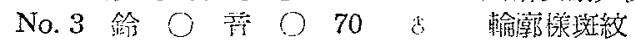

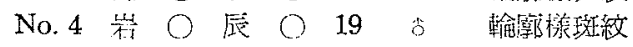

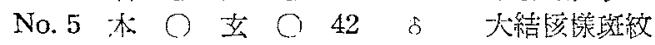

\section{害 験 成 績}

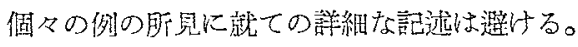

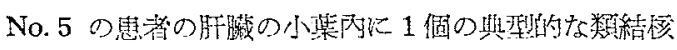

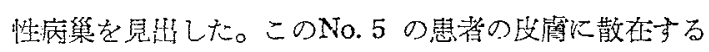
斑较は小明手掌大万玨大人手掌大で, 褐色, 屚平江丘状

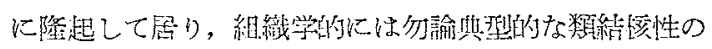

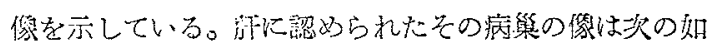


くである。即小葉队化じた比較的輪原の明かな程棈円

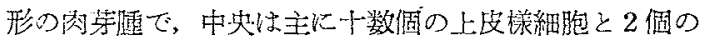
典型的なラングハンス氏巨大細胞よりなり，それらの周 国走多数の淋巴球更少数のブラズ、細胞，勧球，䠌維芽 細胞等が々りまいて外層を權成して居り，父乞れらの緗 胞に混って赤血球が所及飞認められる。中央の上皮㥞細

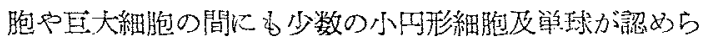
れる。この病樂には菌は認められず。この病雀は染色標 本に於て肉腿で辛うじて認奶うる位の大さであり染色し ない生の標本では因眼で認めがたいるのであったつると 思われる。No. 5 ではこの病巢の他他 1 個の抗酸性菌を 喰してい、星芒状細胞と数個の小凹形細胞よりなる初期

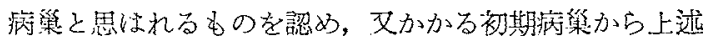

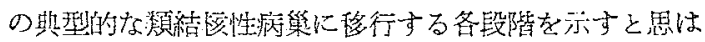

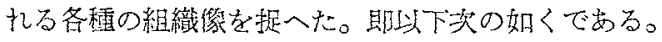

(a) 上述の如民初期の病要

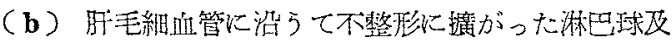
二三の角球よりなる浸潤箱

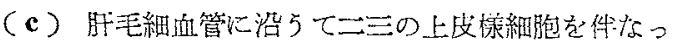

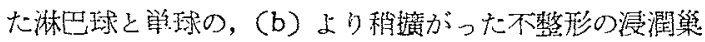

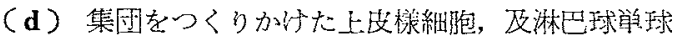

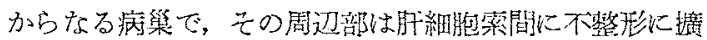
がってはいるが，中央の集盰をつくりかけた上皮稳細胞 を主とする細胞群の中には離算した朋細胞がとり矪され

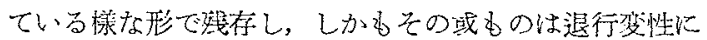
䁰いている。

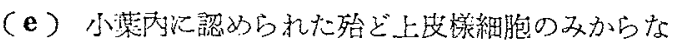
る小集団としての病集

（f）間質にも淋世球，単球，特には上皮樣細胞も加 はる滬潤皀が認められた。

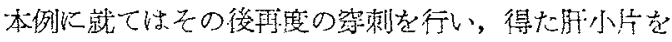

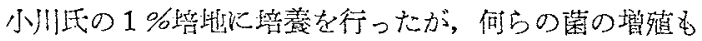

認如られなかった。

他の例儿見ら机た病变に陚て簡単に述べる。

一下記 $(\mathrm{a}),(\mathrm{b}),(\mathrm{c}),(\mathrm{d}),(\mathrm{e}),(\mathrm{f})$ の記号は夫々上述の 組織像の型を意味している。
No. 1
(b) $+($ c $)+(d)+(e)+(f)$

グッッソン氏鞘に認められ大淋巴球，欮球，少数の

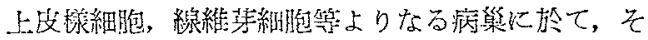

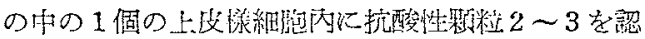

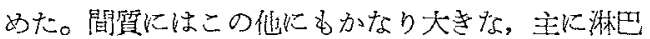
琲, 単球, 線維䓔細胞よりなる浸潤樂が認められ た。
No. 2
(b) $+(c)+(f)$

本例では等刺の祭に小なる組織片しか得られなかっ た。
No. 3
$(\mathrm{a})+(\mathrm{b})+(\mathrm{c})+(\mathrm{d})+(\mathrm{e})+(\mathrm{f})$

(c)琹と(d)型の中間型と思はれる病巢があった。叉

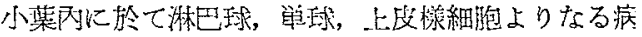

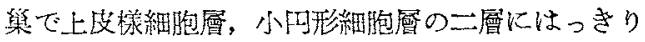
上分れてはいないが，上皮校緗胞は中央に集まる俈

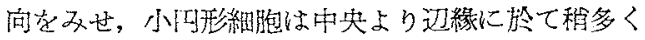
しかも(d)型に比し比校的不整形でなく垻状の像を 示す病焂が見られた。

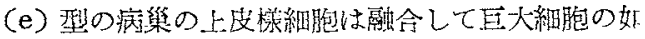
く㒻える。
No. 4
(b) $+($ c $)+(d)+(e)+(f)$

この他の型として上皮悌細胞，淋巴球，単球，線維 芽細胞等が混在する塊状の病樂があり，その上皮㥞 細胞の1つの中に䅞状の抗酸性菌 1 を認めた。 闍質に於て上皮樣細胞が集団をつくり，少数の淋巴 球，線維芽細胞等がそれらの周に認められたものが あった。

\section{考察}

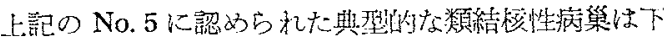

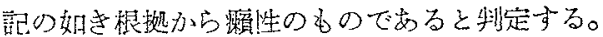

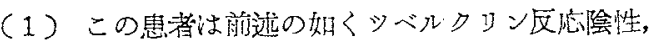

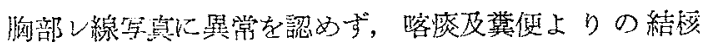

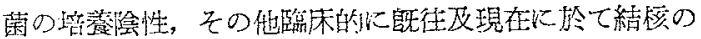
徵侯のない患照である。一般に肝に結核性病变が生ずる には，植めて特殊の湯合を除いては肺，腸等飞或程度の 結核性病变の存在を必要とするものであることを考へる とこの病画は結㤥性のものではないと考へられる。しか もこ0病䒩にこそ抗酸性菌は認められなかったが他の部 位儿於て星芒状細胞內に㜔酸性菌が認められたにる拘ら

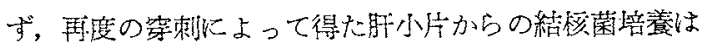
陰性炏終っている。

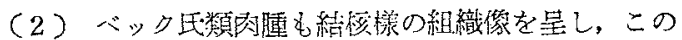
むのと結謈との関係に就ては種々諭争がなされている。 そしてその病变部よりの結核菌培養は陰性に終ることが

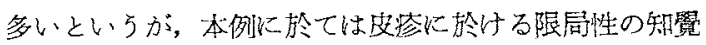

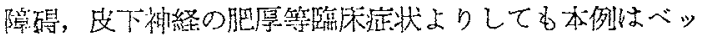
ク氏頪肉䢚の症例ではないと考へられる。

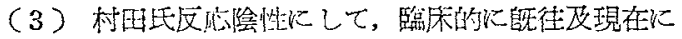

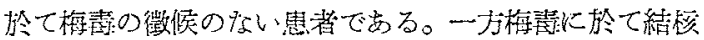
と似た組織像を是するゴム嚙に於ては巨大縕胞は稀に乙 か現れず，上没椂細胞も比較的少いのに反し，木病集に 


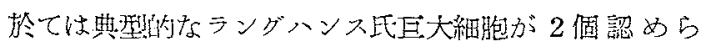

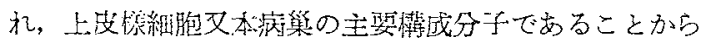

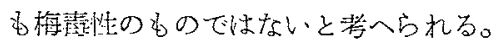

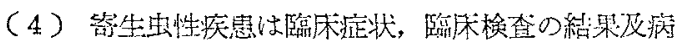
巢の組織所見によって除外しうる。

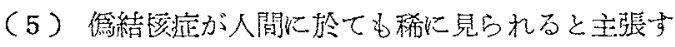

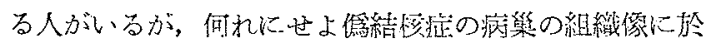
訬る特徵の一つにE大細胞が現れないことでるるいう

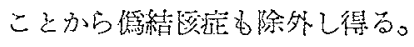

（6）本例飞於て認好られた星造状細胞內の抗酸䚹菌

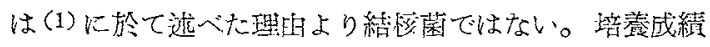
が陰性であったことから非病原性抗婹性菌でもない。彷

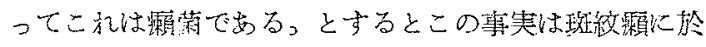
てる颗菌の面行性撒布が起りうることを六している。玨

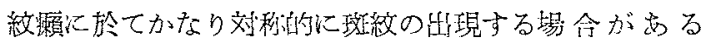
が，このことも血行性の撒布の可能性を䍐隹さる。然ら

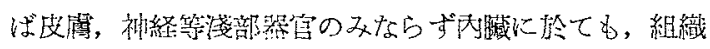

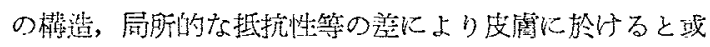

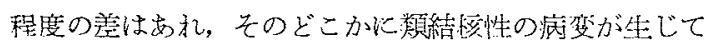
もよい䈏であると考へられる。

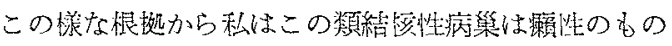

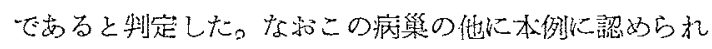

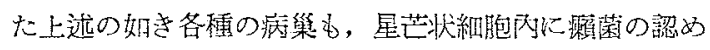

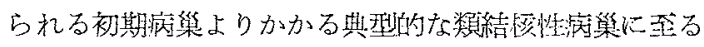
各段階を示していると思われる栐なと机ら相互間の移行 が認められることからしてこれらは何れも一連のもの

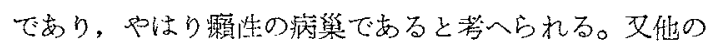

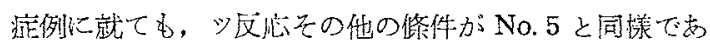
り、それらの症例に認められた病巢の或者に於て㧧酸性 菌が忽められ，琣盖恃行っていないがこれらの抗凌性菌

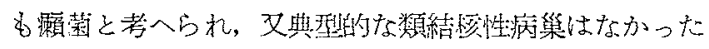

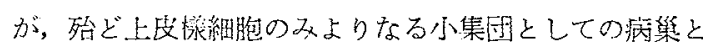
か, 略々上文㥞細胞層と小形細胞娾の二層に分けらる 病樂などの如く，特異な像家示す病䒩及そ机への移行を

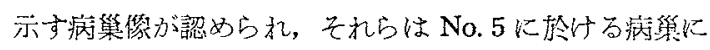

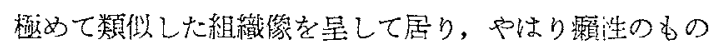
と考へられる。

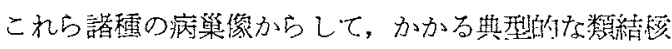

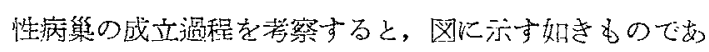

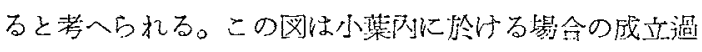

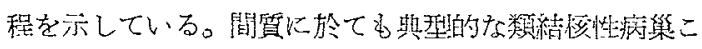
そ認められなかったが，かなりの病殞が認められた。し

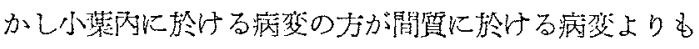

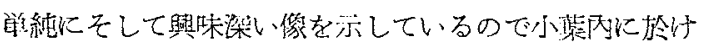

る樋程を艾附图に示した。

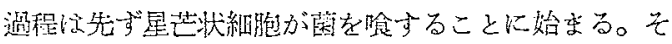

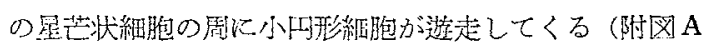

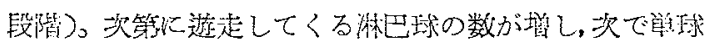

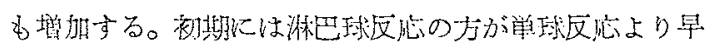

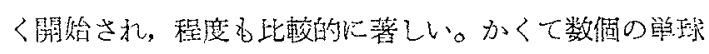

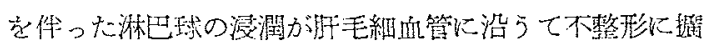

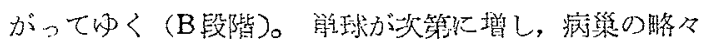

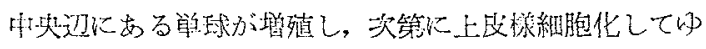
きこれらの細胞が次第に密となってゆくので，ての部

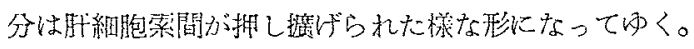
これから先，這程は二つに分れる㥞である。乙進腿が

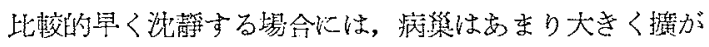

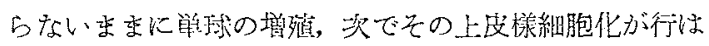

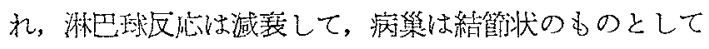
限局化され，少数の淋巴球を混ずるか或は㱠ど上皮栐細 胞のみからなる小集四として限局する(C段階)。進展が

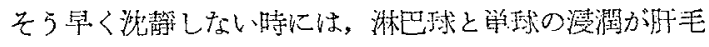

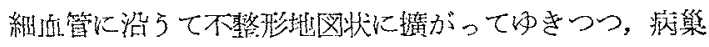

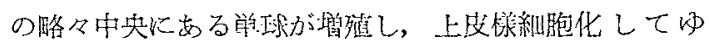

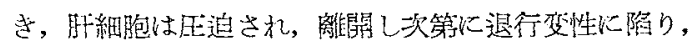

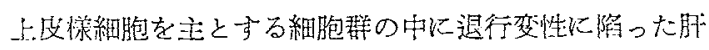
紐胞が残存するに至る(D段階)。更に主に上皮栐細胞か

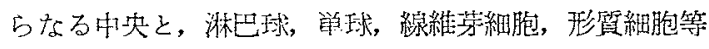

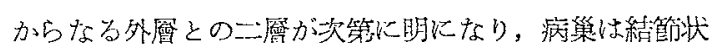
の形火限局するに至る。これは毁に略々其型的な類結核

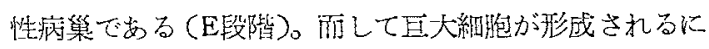
至って類結检性病集としての組織像は更に完成される ( $F$ 段階)。

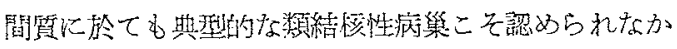
ったが，かなりの病度が認められ，グりッソン民鞘に於

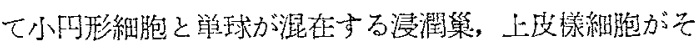
れに加㤝り，その小さな勧団が小四形細胞，単琭と共に

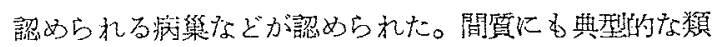
結核性病桼が生ずることがあるかるしれない。その埸合 にはをの成立過程は上述のそれと略々檕を一にしたもの であると思う。

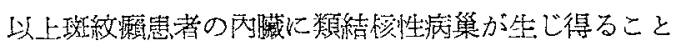

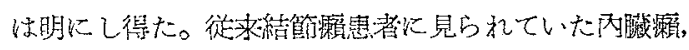

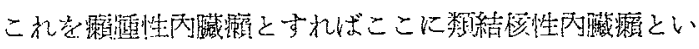

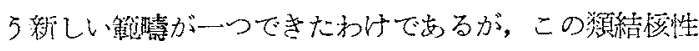

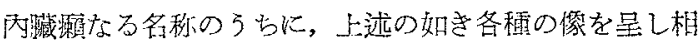
互間比移行のある病樂像の5ら如何なるものまでを包含

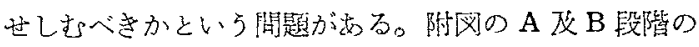




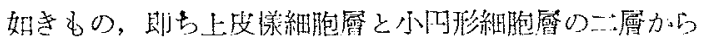

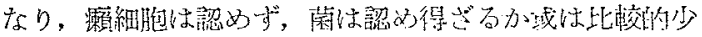

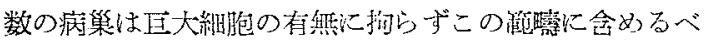
きであることはい5までもない。E或出F段階の如き小

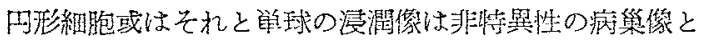
する。小四形細胞，壁球，少数の上皮栐細胞力らなる病集

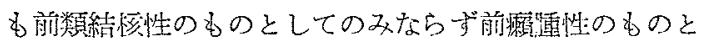
して、ただ待々認められる菌数が比較的多いとい5だけ

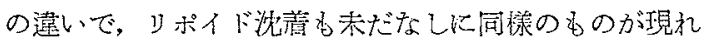
ることがあり，かかるものもやはり非特黑性の病临像と

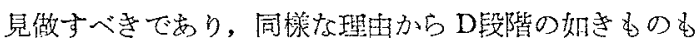

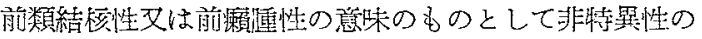
候とすべきである。閶題になるのはC段階の如さ殆ど上

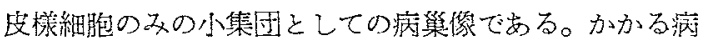

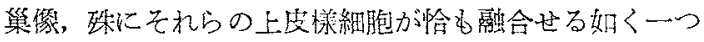

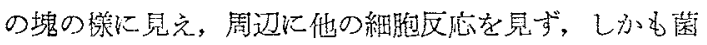

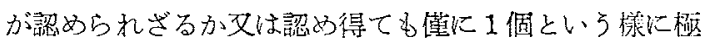
めて少数といらが如き像は，後に述べるが結管型卑者が

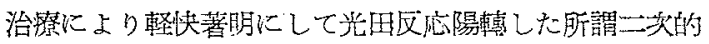

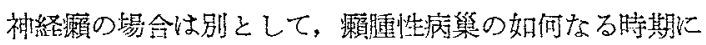
も，又々の前段階としても現れることのないものであ

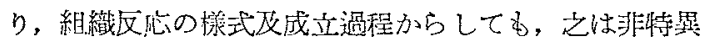
性の病巢像の中に签れるべきではなく，1つの不全型と

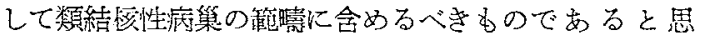
5。又私は一旦典型的な類結检性病學になで進展した疬

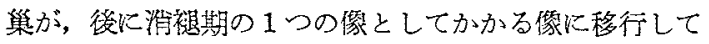
ゆくるのがあるのではないかと考へている。

かく分類すると5例に於ける各型の病樂の出現萑け次

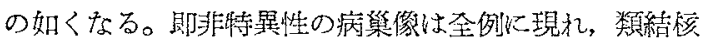
性病菓の不全型は No. 1，3，4，504例飞, 興型的な 類結核性病雀はNo. 501 例儿認められ儿結果となる。

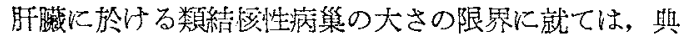
琹的なものは集 1 例で注例が少い為に断定することはで きないが，少くとも今回認めたこの典型的な類結检性病

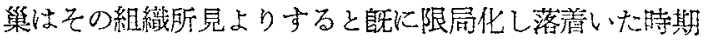
のもので女ると思われ，最早これ众上余り遮大はしない、 のではないかと思われる。とに角私は少くとも肚菭に拎

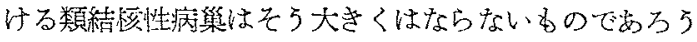
と思占。

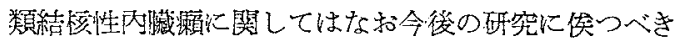

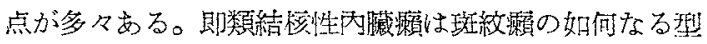
に多いか，そして如何なる時期に発現するのか，発現後 に如何なる推移る迎るか，匣佣の班紋が白斑となる時に 如何なる像に移行するのふ，又結簛瀨に移行する時には

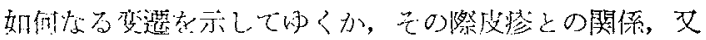

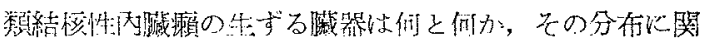

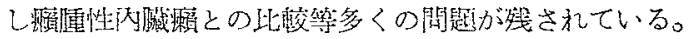

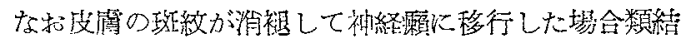

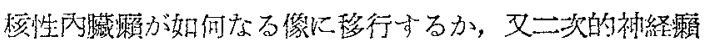

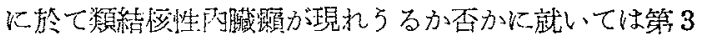

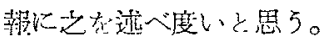

\section{結論}

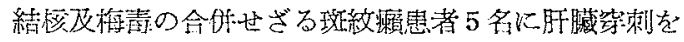

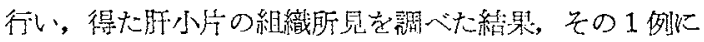

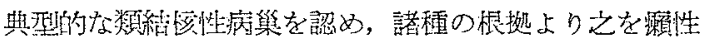

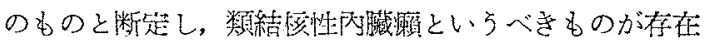
することを確認した。その他に 1 個の瀨菌を嗑した星芒 状細胞と数個の小四形細胞上りなる初期の病樂と思われ

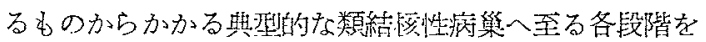
示すと思われる各穗の病策像を捉へ，それらより類結核 性病隹の成立週程を考察した。そして之等备種の病临像

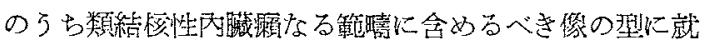

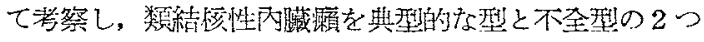

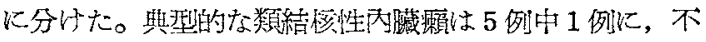
全型は 5 例中 4 例に認められた結果となる。

本研究に当って御指尊を頂いた北村，谷奥，光阳，林，

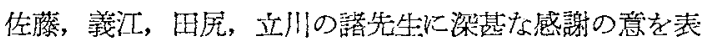
します。ぬた林先先には御校閲の等をとって頂いたこ と，おおせて感謝の意を表します。

\section{主要なる交献}

(1) Olivet, J. : Med. Klin., 1440, 1926.

(2) John Mc Michael : J. Amer. Med. Assoc., $137 ; 234-236$ (No. 3), 1948.

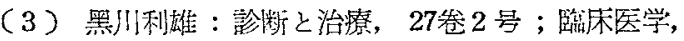
30,833 , 昭 17 ; 東西医学, 8,479 , 昭 16 .

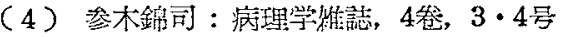

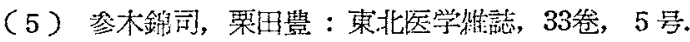

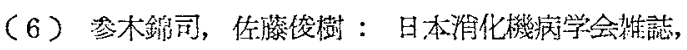
46焱, $1 \cdot 2$ 号

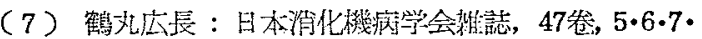
8 믕

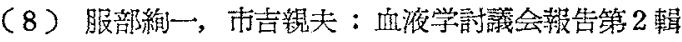

(9) Arning, E. : Verhandl. Deutsch. Dermat. Gezellsch., 441, 1894.

(10) Schäffer, J. : Lepra Bibl. Int., Bd. 1, 1900 ; Bd. 2, 1902.

(11) Rikli, A. : Virchow's Arch., Bd. CXXIX, S. 
110, 1892.

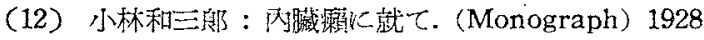

(13) Klingmüller : Die Lepra. Handb. d, Haut-u. Geschl.-Kht., Vol. 10.

(14) Arning, E. : Internat. J. Lepr., Vol. 4, No.1, 1936

(15) 光田健輔：レプラ, 10鹤, 1939.

（16）義江義雄 : レプラ, 13卷, 1942.

(17) Cochrane, R. G. : A Practical Textbook of Leprosy, 1947.

(18) Campos, J. and Molina, M. ; Internal. J. Lepr., Vol. 18, No. 3, 1950.
骂蒖 福 明

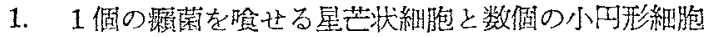
より成る初期の菏策

2. 䀒毛細直管に沿うて不整形地畞状に撗がった小四形

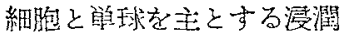

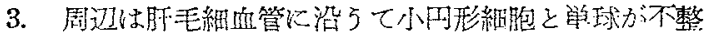
形に㳻がっているが，略マ中央に当る部位ては少数の

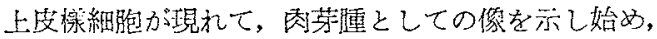

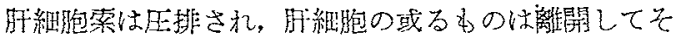
れら細胞の間にとり残されようとしている。

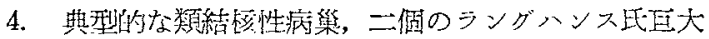
細胞が見える。 
烊田論交附图

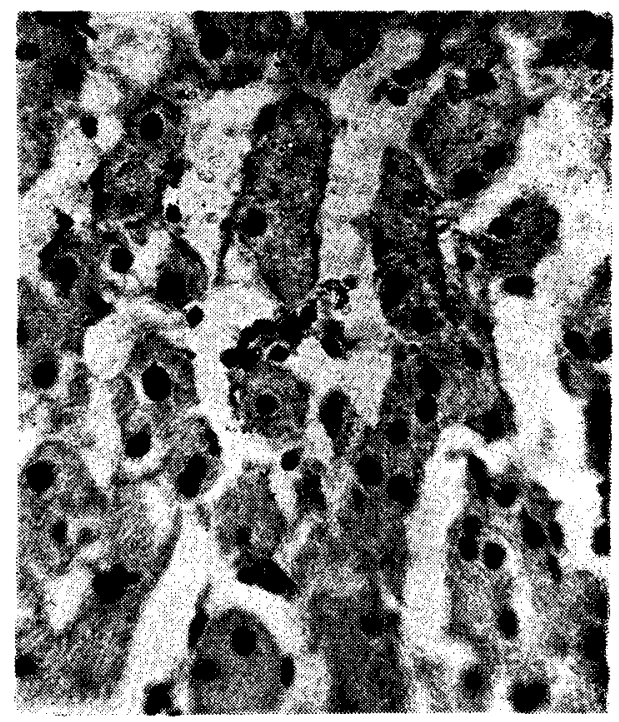

1

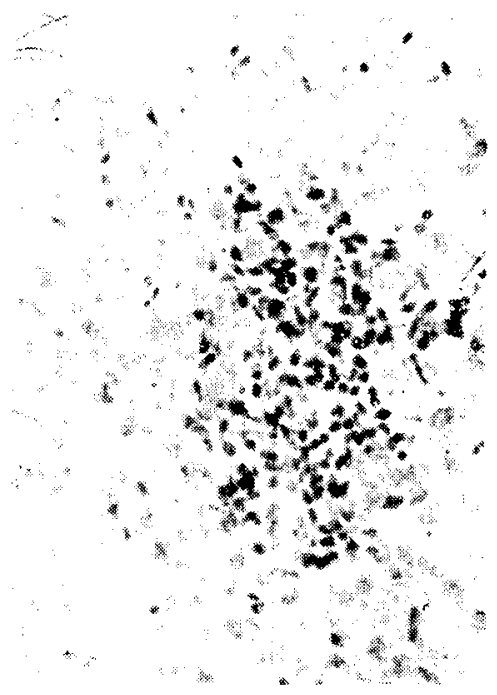

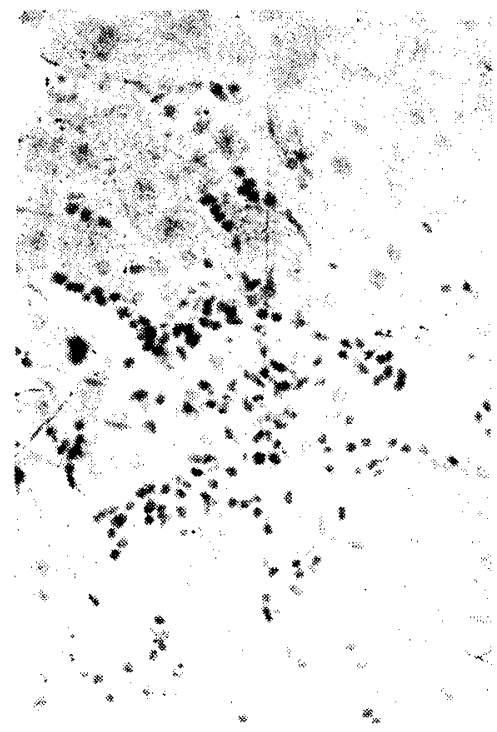

2

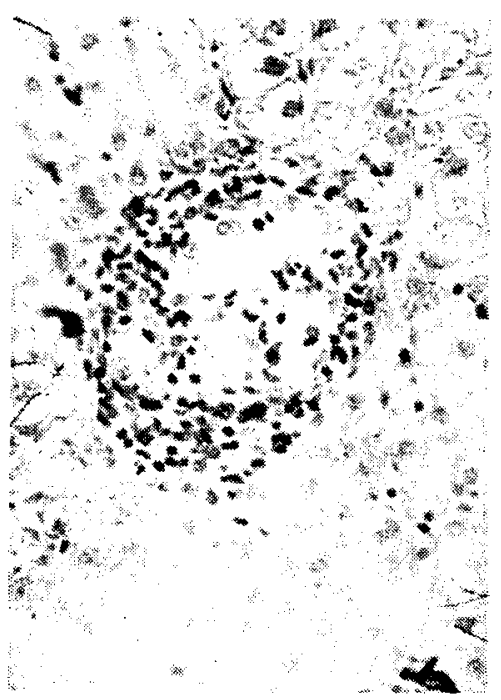




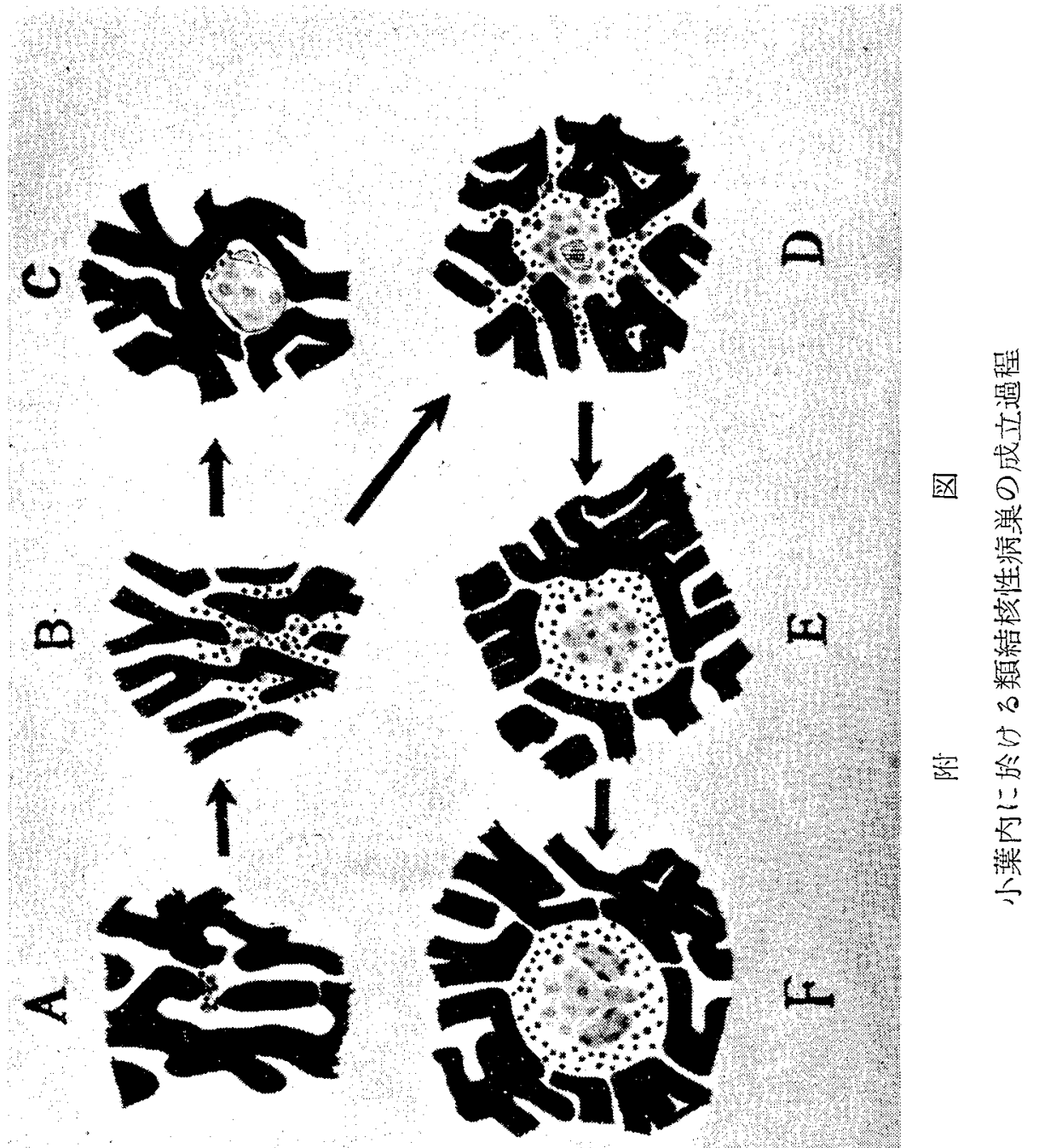

